\title{
IMPROVING THE QUALITY OF THE FRICTION WELDING PROCESS OF STEEL COMPONENTS
}

doi: 10.2478/czoto-2021-0005

Date of submission of the article to the Editor: 12/11/2020

Date of acceptance of the article by the Editor: $31 / 03 / 2021$

\author{
Andrzej Pacana ${ }^{1}$ - orcid id: 0000-0003-1121-6352 \\ Karolina Czerwińska ${ }^{1}$ - orcid id: 0000-0003-2150-0963 \\ ${ }^{1}$ Rzeszow University of Technology, Poland
}

\begin{abstract}
The aim of the study was to implement an integrally configured method of quality control of frictional welding of piston forgings intended for Diesel Man trucks. The use of the method (consisting of the $5 \mathrm{~W} 2 \mathrm{H}$ method, the Ishikawa diagram and the ABCD - Suzuki method) would contribute to the detection of the causes of noncompliance and consequently to the elimination of non-compliant products. Steel pistons have become the subject of research due to significant problems with maintaining their expected level of quality after the introduced structural and technological changes. The proposed method has helped to identify the root cause of non-compliance. It was: incorrect design of the combustion chamber in terms of diameter and depth. The study shows that it is advisable to use an integrated approach to finding the causes of quality problems on the example of the friction welding process. This was a new solution for the company, as no in-depth analyses of quality problems using a sequence of quality management techniques have been carried out so far.
\end{abstract}

Keywords: friction welding, mechanical engineering, quality engineering, quality management tools

\section{INTRODUCTION}

Continuous development of technology and special operating conditions of rulers and machines contribute to the increase in requirements for construction materials and thus to the necessity to develop and apply new technologies (Budzik and Jaskólski, 2004; Melton, 2005; Staniszewska, et al., 2020; Zima, 2005). Currently, reciprocating diesel engines are one of the most important energy sources used to drive both trucks and passenger cars. Of all the components of an internal combustion engine, the piston is the element most exposed to thermal damage. This element is a movable part of the combustion chamber and should therefore have appropriate quality parameters - inter alia resistance to high pressures and temperatures (Budzik and Jaskólski, 2004; Czerwińska and Pacana, 2016). The legal conditions concerning restrictions on the emission of toxic exhaust substances generated by internal combustion engines force vehicle manufacturers to take care of improving the technology and quality of 
manufactured products (their physicochemical properties and functional features) (Czerwińska et al., 2019; Langabeer, 2018; Salacinski et al., 2018).

Comprehensive methods of non-compliance detection are constantly being searched for and, at the same time, attempts are being made to prevent them by detecting the sources of their origin or even conducting analyses to identify the causes that cause quality problems in these sources (Liu et al., 2011). The methods enabling the realization of the presented undertakings are quality management methods, which, if used correctly, allow to increase the quality level of manufactured products (Chang, 2004, Langabeer, 2018; Pacana and Czerwińska, 2020; Pawlowski and Pawlowski, 2018).

\section{FRICTION WELDING}

The friction welding method, together with its numerous variations, is one of the most dynamically developed technologies of thermal bonding in a constant state. This is due to the numerous advantages of the method, not only for riveting and bonding, but also for welding, soldering and other welding methods (Kudła et al., 2013).

Rotary friction welding is a process in which the heat needed to create a permanent connection is created by friction in the contact area of the welded elements as a result of direct conversion of mechanical energy into heat energy. The essence of the process is to produce a joint by welding in a constant state. The joint is obtained by plastic deformation of the material at the point of contact of the parts being joined. The mechanical friction energy heats up the contact area to a highly plasticised state. Moreover, the exertion of the clamping force and the approximation of the clean metallic surfaces of the element at a distance close to the network parameter results in a permanent metallic connection in a constant state (Ferenc et al., 2015; Pietrzak et al., 2011, Salacinski et al., 2018). Scaling is created by mechanically and thermally activated high gradient diffusion processes, as well as by dissolving and crushing oxides, creating new grain boundaries, and by common crystallization of the material in the friction area (Kimpong and Watanabe, 2004; Sato et al., 2002).

Currently, by friction welding, parts made of alloy steels, carbon steels, pure metals such as copper, aluminum, nickel are joined. A significant advantage of friction welding is the possibility of obtaining, almost in a few dozen seconds, qualitatively good joints of various compositions of materials which are not easy to combine with other techniques, such as alloyed steels and aluminium or copper and aluminium (Xu, 2020; Zhang et al., 2020]. The advantages of this type of joints also include the lack of metal clumping shrinkage, the fact that the heat affected zones are not heated and thus not weakened by softening effects, as well as a very high coefficient of so-called technological reliability, i.e. very low spread of mechanical properties (Wang et al. 2020; Wei et al. 2020).

\section{ANALYSIS}

\section{Aim, scope and subject matter}

The purpose of the tests is to diagnose, by means of a visual test method, the condition of the steel piston after the friction welding process. The semi-finished products for pretreatment before welding are drop-forged steel forgings (Figure 1a). The aim of the study is also to identify the sources of non-compliance of the workpiece after the friction welding process and, ultimately, with the help of quality management tools (Ishikawa 
diagram and $5 \mathrm{~W} 2 \mathrm{H}$ ), reduce the occurrence of non-compliant products or eliminate them altogether.

Due to the increase in the number of non-compliant products identified during the inservice inspections ( $3 \%$ compared to the previous quarter) and the number of complaints, the steel piston for diesel Man trucks was tested (Figure 1b).

a)

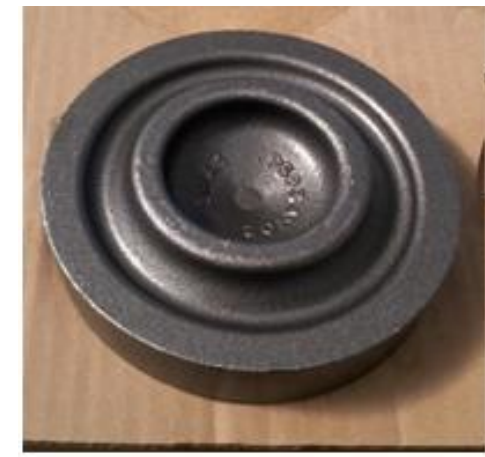

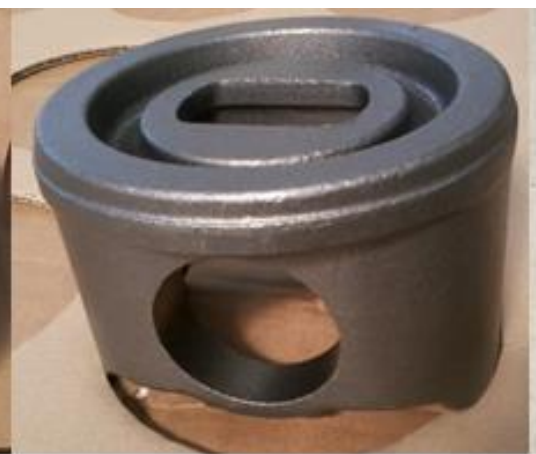

b)

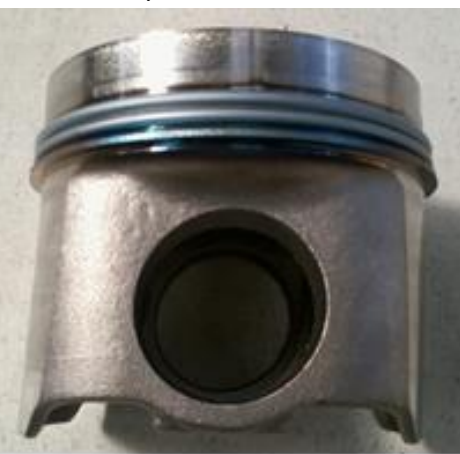

Fig. 1. Subject of the tests a) upper and lower part of the piston b) the piston after welding

The survey concerned a batch of details made in Q3 2019 in one of the automotive companies, which is located in the southern part of Poland. The company produces steel and aluminium pistons for trucks and passenger vehicles. The scope of visual testing covered the surfaces of the entire product.

\section{Alloy characteristics}

38MnVS6 (38MnSiVS5) is a high-strength steel based on Mn-V. It is a high-grade lowalloy steel with good machinability for controlled cooling from working heat (BY machining, condition + P according to DIN EN 10267). Steel 38MnVS6 is in the group of ferritic-perlite dispersion-hardened steels according to DINEN 10267 (Silva et al., 2011). The chemical composition of the alloy and its mechanical properties are shown in Table 1.

Table 1

Chemical composition and mechanical properties of steel 38MnVS6 [17]

\begin{tabular}{|c|c|c|c|c|c|c|c|c|c|c|}
\hline \multicolumn{11}{|c|}{ Chemical composition } \\
\hline Element & \multicolumn{2}{|l|}{$\mathbf{C}$} & Si & $\mathbf{M n}$ & $\mathbf{P}$ & $\mathbf{S}$ & $\mathrm{Cr}$ & Mo & $\mathbf{V}$ & $\mathbf{N}$ \\
\hline Min, [\%] & 0,3 & & 0,15 & 1,20 & \multirow{2}{*}{$<0,025$} & 0,020 & \multirow{2}{*}{$<0,30$} & \multirow{2}{*}{$<0,08$} & 0,08 & 0,01 \\
\hline Max, [\%] & 0,4 & & 0,80 & 1,60 & & 0,060 & & & 0,20 & 0,02 \\
\hline \multicolumn{11}{|c|}{ Mechanical properties } \\
\hline \multicolumn{2}{|c|}{$\begin{array}{l}\text { 0,2\% proof stress } \\
\mathbf{R}_{\mathrm{p} 0,2}\left[\mathrm{~N} / \mathrm{mm}^{2}\right]\end{array}$} & \multicolumn{3}{|c|}{$\begin{array}{l}\text { Tensile } \\
R_{\mathrm{m}}\left[\mathrm{N} / \mathrm{mm}^{2}\right]\end{array}$} & \multicolumn{3}{|c|}{\begin{tabular}{l|l}
$\mathrm{F}$ & $\begin{array}{l}\text { Fracture elongation } \\
\mathbf{A}_{5}[\%]\end{array}$
\end{tabular}} & \multicolumn{3}{|c|}{$\begin{array}{l}\text { Reduction of area } \\
\mathrm{Z}[\%]\end{array}$} \\
\hline \multicolumn{2}{|l|}{ Min 520} & \multicolumn{3}{|c|}{$800-950$} & \multicolumn{3}{|c|}{ Min 15} & \multicolumn{3}{|c|}{ Min 25} \\
\hline
\end{tabular}

The alloy is used for automotive parts such as gear shafts, tappets, rotary bearings, axle pivots, hubs and piston heads (Singh et al., 2017).

\section{Testing procedure}

The methods used to control the quality of the welded piggyback forgings - identification and characterization of nonconformities - were vision testing and quality management 
techniques, (5W2H method, Ishikawa diagram, ABCD method - Suzuki). The correlation of diagnostic methods and their sequence of application is shown in Figure 2. Visual examination, in a company producing pistons, is performed by employees after each technological operation.

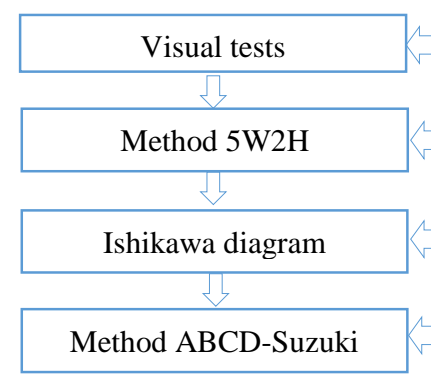

Identification of non-compliance on the frictional welding surface of the piston

Implementation of the gemba walk and definition of the problem

Analysis and grouping of potential causes of non-compliance

The expert group's determination of the importance and rank of individual causes - identification of the most important cause of the problem

Fig. 2. A sequence of methods used to analyse nonconformities and identify the source of their occurrence

The incompatibility was characterized and analyzed using the $5 \mathrm{~W} 2 \mathrm{H}$ method, the Ishikawa diagram and the ABCD-Suzuki method. The $5 \mathrm{~W} 2 \mathrm{H}$ method was used to gather and present in a short and clear way the most important information about the problem. Ishikawa's diagram was used to list the potential causes of non-compliance within the five classical categories $(5 \mathrm{M})$ : man, machine, material, method and management, while using the ABCD - Suzuki method, an appointed team of experts determined the validity and rank of the individual causes.

\section{RESULTS}

The research was carried out by a working team consisting of: the Head of the Department of Health and Consumer Protection. Quality, chief technologist, quality control employee and friction welding station employee. The study analysed all noncompliant products identified during the third quarter of 2019. An example of the obtained results of visual testing of the friction welding area of the piston forgings is shown in Figure 3. The presented result of the quality control refers to the most serious and most frequent defect that occurred after the welding process.

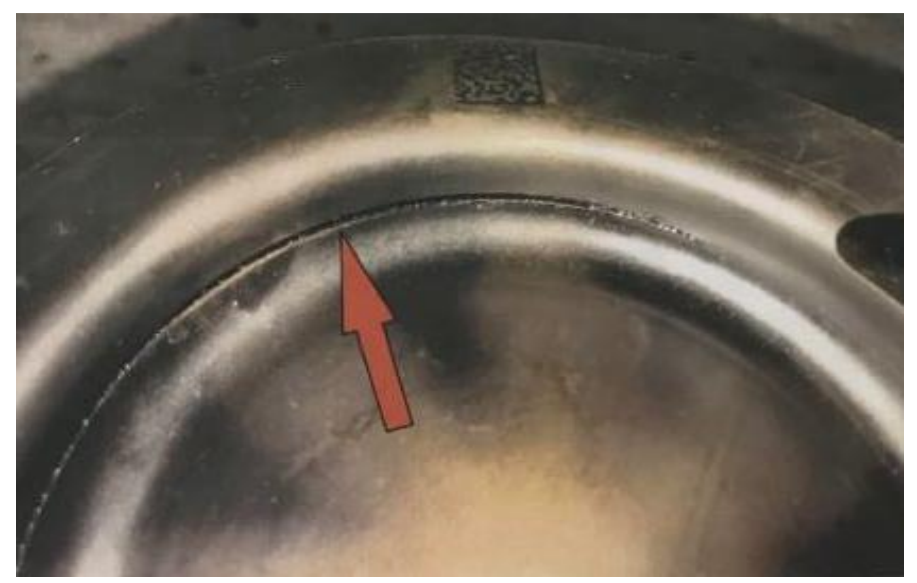

Fig. 3. The result of visual tests carried out after the friction welding process

The obtained results of the visual inspection indicate the occurrence of an unacceptable incompatibility in the load zone - burnt-out steel piston combustion chamber. An identified forgery connection anomaly disqualifies the piston. 
In the next step, the appointed working team performed a gemba of fights and then, in order to precisely characterise the problem, carried out a $5 \mathrm{~W} 2 \mathrm{H}$ analysis (Table 2).

Table 2

$5 \mathrm{~W} 2 \mathrm{H}$ method for casting discontinuity problem

\begin{tabular}{|l|l|l|}
\hline Question & Answer \\
\hline Who? & $\begin{array}{l}\text { Who has detected the } \\
\text { problem? }\end{array}$ & The employee who performed the visual check \\
\hline What? & What is the problem? & Burnt steel piston combustion chamber \\
\hline Why? & Why is this a problem? & $\begin{array}{l}\text { Failure to meet standards - product } \\
\text { disqualification }\end{array}$ \\
\hline Where? & $\begin{array}{l}\text { Where was the problem } \\
\text { detected? }\end{array}$ & $\begin{array}{l}\text { In the area of the piston combustion chamber - } \\
\text { the friction heating area of the forgings }\end{array}$ \\
\hline When? & $\begin{array}{l}\text { When was the problem } \\
\text { detected? }\end{array}$ & $\begin{array}{l}\text { During the visual inspection carried out } \\
\text { immediately after the technological operation - } \\
\text { friction welding }\end{array}$ \\
\hline How? & $\begin{array}{l}\text { How was the problem } \\
\text { detected? }\end{array}$ & $\begin{array}{l}\text { Non-compliance was detected during visual } \\
\text { inspection with an unarmed eye of normal } \\
\text { visual acuity }\end{array}$ \\
\hline $\begin{array}{l}\text { How } \\
\text { much? }\end{array}$ & How big is the problem? & $\begin{array}{l}\text { 5\% of products manufactured in the third } \\
\text { quarter of 2019. }\end{array}$ \\
\hline
\end{tabular}

The next step of the analysis was to perform the Ishikawa diagram in order to list the most probable causes of non-compliance and classify them according to the following categories: man, machine, material, method, management (Figure 4).

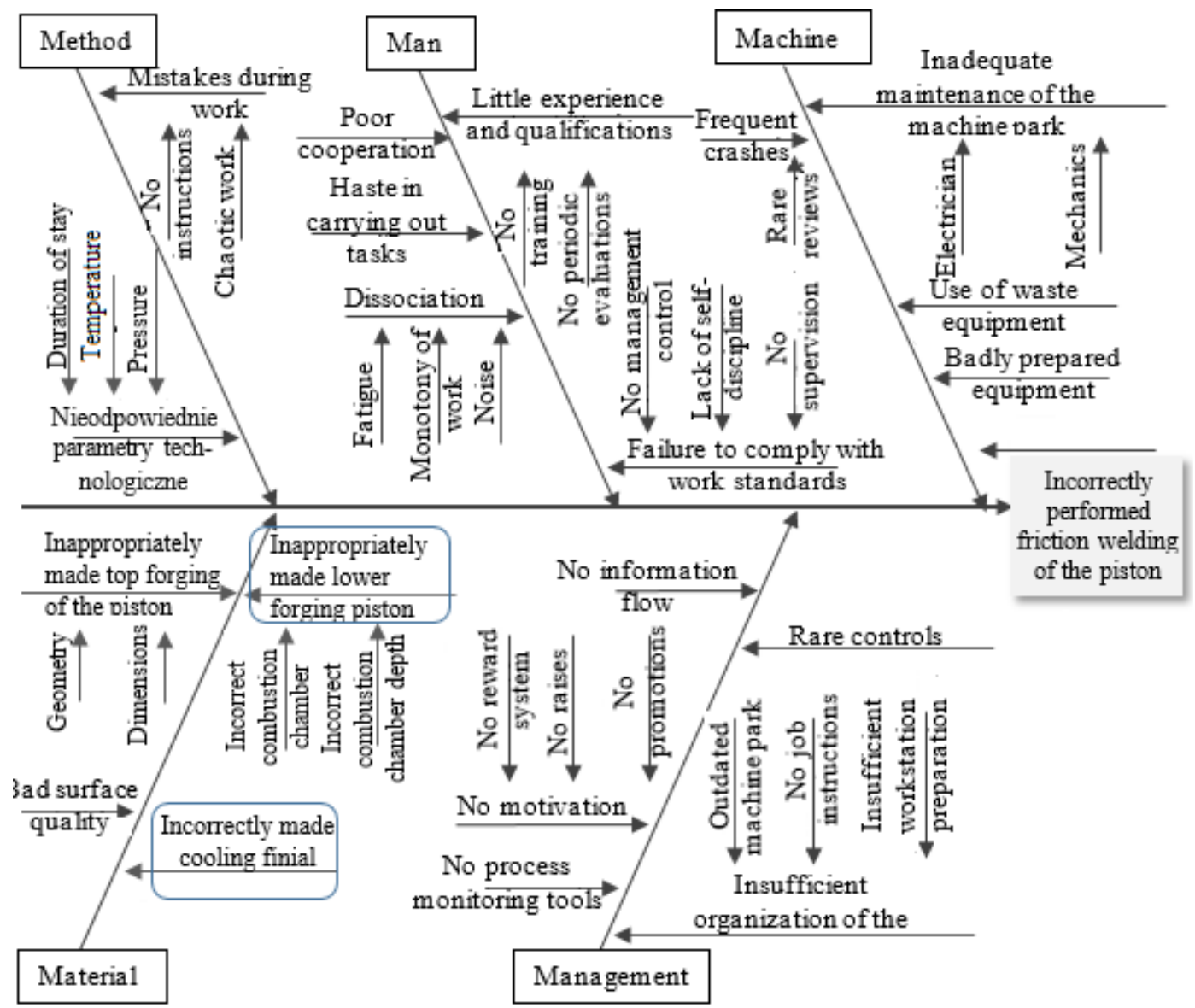

Fig. 4. Ishikawa diagram for non-compliance - incorrectly made piston friction welding 
Based on the Ishikawa diagram relating to the problem of incorrect sealing of the piston forgings, namely the burning of the sealing area within the piston combustion chamber, a significant number of potential causes of non-compliance are listed. The team of experts used the ABCD-Suzuki method to indicate the importance and rank of particular potential causes. The result of the analysis (the most relevant reasons for noncompliance) is presented in Table 3.

Table 3

Summary of results of the ABCD-Suzuki method for the problem of discontinuity of the casting

\begin{tabular}{|c|c|c|c|c|c|c|c|c|c|c|c|c|c|c|}
\hline \multirow{2}{*}{$\begin{array}{l}\text { Reason for non- } \\
\text { compliance }\end{array}$} & \multicolumn{10}{|c|}{ Rank of criteria } & \multirow{2}{*}{ 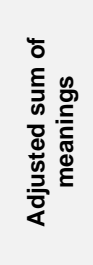 } & \multirow{2}{*}{ 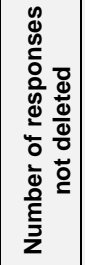 } & \multirow{2}{*}{ 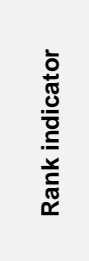 } & \multirow{2}{*}{ 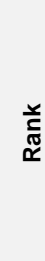 } \\
\hline & 1 & 2 & 3 & 4 & 5 & 6 & 7 & 8 & 9 & 10 & & & & \\
\hline $\begin{array}{l}\text { Wrong cooling channel } \\
\text { depth }\end{array}$ & 3 & 3 & 6 & 2 & 1 & & & & & & 31 & & 2.38 & 3 \\
\hline $\begin{array}{l}\text { Wrong width of the cooling } \\
\text { channel }\end{array}$ & 1 & 5 & 5 & 2 & & 1 & 0 & & & & 34 & & 2.62 & 4 \\
\hline $\begin{array}{l}\text { Non-parallel cooling } \\
\text { channel to the piston } \\
\text { crown }\end{array}$ & 0 & 5 & 2 & 6 & 0 & & & & & & 40 & & 3.08 & 5 \\
\hline $\begin{array}{l}\text { Incorrect combustion } \\
\text { chamber diameter }\end{array}$ & 5 & 5 & 1 & 1 & & 1 & 0 & & & & 28 & 13 & 2.15 & 1 \\
\hline $\begin{array}{l}\text { Incorrect combustion } \\
\text { chamber depth }\end{array}$ & 4 & 4 & 3 & 3 & 2 & & & & & & 29 & & 2.23 & 2 \\
\hline $\begin{array}{l}\text { Incorrect fastening of the } \\
\text { bottom (top od-off) }\end{array}$ & 3 & 2 & 4 & 1 & & 3 & 0 & & & & 41 & & 3.15 & 6 \\
\hline $\begin{array}{l}\text { Incorrect technological } \\
\text { parameters }\end{array}$ & 0 & 4 & 4 & 4 & 2 & 1 & & & & & 41 & & 3.15 & 7 \\
\hline
\end{tabular}

As a result of the analyses carried out, it turned out that the three most important reasons for incorrect performance of friction welding (in order of importance) were: incorrect diameter of the combustion chamber, incorrect depth of the combustion chamber, incorrect depth of the cooling channel.

\section{DISCUSSION AND CONCLUSION}

In the paper a diagnostic test (visual inspection) used in the quality control of steel pistons was carried out and the results were analysed with the use of quality management tools. The aim of the tests was to identify non-compliant products and check the usefulness of control and diagnostic testing in the production area.

By means of a visual inspection, an incompatibility was detected in the area of the piston combustion chamber - burning out after the frictional welding process. The presence of an identified non-compliance disqualifies the piston. In order to characterise the problem, a team of experts performed a gemba of fights and a $5 \mathrm{~W} 2 \mathrm{H}$ analysis. In order to identify the causes of non-compliance, an Ishikawa diagram was drawn up, while the ABCD-Suzuki method was used to indicate the validity and rank of individual potential causes, according to which the main cause of non-compliance was incorrect design of the combustion chamber in terms of diameter and depth. 
The diagnostic test method used in combination with the quality management methods are largely complementary. This combination can be useful in terms of methods supporting quality management processes. Traditional $5 \mathrm{~W} 2 \mathrm{H}$ method can be extremely useful by using it in the analysis cycle, where the output of one tool is an input to the next quality management method.

\section{REFERENCES}

Budzik, G., Jaskólski, J., 2004. Obciążenia cieplne tłoków silników spalinowych, Oficyna Wydawnicza Politechniki Rzeszowskiej, Rzeszów, 3075-3082.

Chang, AS., 2004. Control points and measures of a quality process, International Journal of Materials \& Product Technology, 20(1-3), 205-209.

Czerwińska, K., Dwornicka, R., Pacana, A., 2019. Analysis of non-compliance for the cast of the industrial robot basis, METAL 2019: 28th International Conference on Metallurgy and Materials, Brno, Tanger LTD.

Czerwińska, K., Pacana, A., 2016. Application eddy currents inthe control quality piston diesel, Interdisciplinarity in Theory and Practice, 11, 30-32.

Ferenc, K., Cegielski, P., Chmielewski, T., 2015. Technika spawalnicza w praktyce, Poradnik inżyniera konstruktora i technologa, Verlag Dashofer, Warszawa.

Kimpong, K., Watanabe, T., 2004. Friction Stir Welding of Aluminum Alloy to Steel, Welding Journal, October, 277-282.

Kudła, K., Wojsy, K., Kucharczyk, Z., 2013. Własności zakładkowych złączy spajanych metodą zgrzewania tarciowego z przemieszaniem (FSW - Friction Stir Welding), Obróbka Plastyczna Metali, 24(3), 179-191.

Langabeer, JR., 2018. Performance management methods and tools, Performance Improvement in Hospitals and Health Systems: Managing Analytics and Quality in Healthcare, 2nd Edition, 43-61.

Liu, MZ., Zhao, ZB., Jiang, ZQ., Ge, MG., Ling, L., Luo, Y., Wang, XQ., 2011. Research of correlation-model between qualities attributes and quality control points in assembly process of the complex product based on network flow, Advanced Materials Research, 403-408, 3015.

Melton, T., 2005. The benefits of lean manufacturing - What lean thinking has to offer the process industries, Chemical Engineering Research \& Design, 83(6), 662-673.

Pacana, A., Czerwińska, K., Bednarowa, L., 2018. Comprehensive improvement of the surface quality of the diesel engine piston, Metalirgija, 58, 3-4, 329-332.

Pacana, A., Czerwińska, K., 2020. Improving the quality level in the automotive industry, Production Engineering Archives, 26(4), 162-166.

https://doi.org/10.30657/pea.2020.26.29

Pawlowski, K., Pawlowski, E., 2018. Complementarity of modern management methods and tools, and its impact on economic and organizational performance of enterprises, Empirical Results from Polish Enterprises, Advances in Ergonomics of Manufacturing: Managing the Enterprise of the Future, 606, 213-221.

Pietrzak, K., Kaliński, D., Chmielewski, M., Chmielewski, T., Włosiński, W., Choręgiewicz, K. 2011. Processing of intermetallics with Al2O3 or steel joints obtained by friction welding technique, 12th Conference of the European Ceramic Society - ECerS XII, Stockholm.

Salacinski, T., Chmielewski, T., Winiarski, M., Cacko, R., Świercz, R., 2018. Roughness of Metal Surface After Finishing Using Ceramic Brush Tools, Advances in Materials Science, 18(1), 20-27. 
Seyanin, IF., Deev, VB., Kukharenko, AV., 2015. Resource-saving and environmentsaving production technologies of secondary aluminum alloys, Russian Journal of Non-Ferrous Metals, 56(3), 272-276.

Silva, MLN., Pires, GH., Button, ST., 2011. Damage evolution during cross wedge rolling of steel DIN 38MnSiVS5, 11TH International Conference on the Mechanical Behavior of Materials (Icm11), Procedia Engineering, 10.

Singh, P., Batra, U., Sangal, S., 2017. Fracture Toughness Behavior of 38MnSiVS5 Microalloyed Steel After Isothermal Transformation and Thermomechanical Processing, Materials Today-Proceedings, 4(8), 8528-8537.

Wang, HD., Wang, KS., Wang, W., Lu, YX., Peng, P., Han, P., Qiao, K., Liu, ZH., Wang, L., 2020. Microstructure and Mechanical Properties of Low-Carbon Q235 Steel Welded Using Friction Stir Welding, Acta Metallurgica Sinica-English Letters.

Wei, YN., Li, H., Xiao, P., Zou, JT., 2020. Microstructure and Conductivity of the Al-Cu Joint Processed by Friction Stir Welding, Advances in Materials Science and Engineering, 2020, 6845468, 1-10.

Xu, XX., You, GQ., Ding, Yh., Tong, X., Zai, L., Liu, Q., 2020. Microstructure and mechanical properties of inertia friction welded joints between high-strength lowalloy steel and medium carbon steel, Journal of Materials Processing Technology, 286, 116811.

Sato, Y.S., Urata, M., Kokawa, H., 2002. Parameters controlling microstructure and hardness during friction-stir welding of precipitation-hardenable, Metallurgical and Materials Transactions A, 33A, March, 625-635.

Staniszewska, E., Klimecka-Tatar, D., Obrecht, M., 2020. Eco-design processes in the automotive industry. Production Engineering Archives, 26(4), 131-137. https://doi.org/10.30657/pea.2020.26.25

Zhang, CH., Huang, GJ., Cao, Y., Zhu, Yl., Huang, XD., Zhou, Y., Li, QI., Zeng, QH., Liu, Q., 2020. Microstructure evolution of thermo-mechanically affected zone in dissimilar AA2024/7075 joint produced by friction stir welding, VACUUM, 179, 109515.

Zima, S., 2005. Motorkolben: Bauarten, Betrieb, Schäden. Vieweg Verlag, 278. 